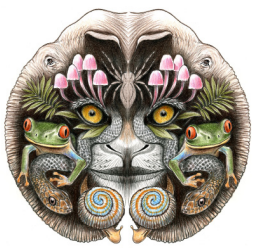

ISSN

Online 0974-7907

Print 0974-7893

OPEN ACCESS

\title{
ON the Status OF SNOW LEOPARD PANTHERA UNCIA (SCHREBeR, 1775) IN ANNAPURNA, NEPAL
}

\author{
Som B. Ale ${ }^{1}$, Bikram Shrestha ${ }^{2}$ \& Rodney Jackson ${ }^{3}$ \\ ${ }^{1}$ Biological Sciences, University of Illinois-Chicago, 845 West Taylor Street, Chicago, IL 60607, USA \\ ${ }^{2}$ Snow Leopard Conservancy-Nepal program, NTNC/ACAP HQ, Hariyo Kharka, Pokhara, Nepal \\ ${ }^{1,3}$ Snow Leopard Conservancy, 18030 Comstock Avenue, Sonoma, CA 95476, USA \\ ${ }^{1}$ sale1@uic.edu (corresponding author), ${ }^{2}$ bikramone@gmail.com, ${ }^{3}$ rodjackson@mountain.org
}

\begin{abstract}
We conducted a status-survey on Snow Leopard Panthera uncia and its main prey, the Blue Sheep Pseudois nayaur, in the Mustang District of Nepal's Annapurna Conservation Area, in 2010 and 2011. Sign transects, covering a total linear distance of 19.4km, revealed an average density of 5.8 signs per kilometer, which compares with those from other Snow Leopard range countries. This also roughly corresponded with the minimum number of three adult Snow Leopards we obtained from nine remote cameras, deployed to monitor areas of c. $75 \mathrm{~km}^{2}$ in extent. We obtained 42 pictures of Snow Leopards during nine capture events. We conclude that Mustang harbors at least three adult Snow Leopards, and probably more, along with a healthy Blue Sheep population (a total of 528 individuals, along $37.6 \mathrm{~km}$ of Snow Leopard transect lines). We suggest that people-wildlife conflicts exist but that the local people tolerate Snow Leopards based on their Buddhist socio-religious values.
\end{abstract}

Keywords: Annapurna, Blue Sheep, Buddhism, camera-trapping, Himalayas, Mustang, sign-survey, Snow Leopard.

DOI: http://dx.doi.org/10.11609/JoTT.03635.5534-43| ZooBank: urn:Isid:zoobank.org:pub:CAB76A86-19AA-4B22-ACE2-EEEF27ACBA8A

Editor: Hem Sagar Baral, Zoological Society of London - Nepal Office, Kathmandu, Nepal.

Date of publication: 26 March 2014 (online \& print)

Manuscript details: Ms \# 03635 | Received 24 May 2013 | Final received 17 March 2014 | Finally accepted 19 March 2014

Citation: Ale, S.B., B. Shrestha \& R. Jackson (2014). On the status of Snow Leopard Panthera uncia (Schreber, 1775) in Annapurna, Nepal. Journal of Threatened Taxa 6(3): 5534-5543; http://dx.doi.org/10.11609/JoTT.03635.5534-43

Copyright: (c) Ale et al. 2014. Creative Commons Attribution 3.0 Unported License. JoTT allows unrestricted use of this article in any medium, reproduction and distribution by providing adequate credit to the authors and the source of publication.

Funding: The major funding for this research came from Snow Leopard Conservancy (SLC-Nepal program) and RSG/Booster grant (Snow Leopards Corridor Project), while other supports (e.g., logistic) came from National Trust for Nature Conservation and CzechGlobe (Global Change Research Center AS CR).

Competing Interest: The authors declare no competing interests.

Author Contribution: All authors have equal contributions in designing and undertaking the field work and data-collection, and writing the manuscript.

Author Details: SOM ALE has been working for Snow Leopard research, education and conservation in Nepal since 1993, first as the professional staff of the National Trust for Nature Conservation, and now as the regional conservation director of the Snow Leopard Conservancy. He teaches at the University of Illinois at Chicago, USA. BIKRAM SHRESTHA completed his M.Sc. in 2003 from Tribhuvan University of Nepal. Since his graduation, he has been actively involved in Snow Leopard and other wildlife research in the mountains of Nepal. He teaches wildlife biology at the Institute of Forestry, Pokhara Campus, Nepal. RODNEY JACKSON is the founding director of the Snow Leopard Conservancy, the US-based nonprofit, established in 2000. He was also the first biologist to radio-collar and embarked on the classic study on Snow Leopard ecology and behavior in remote Dolpo District in Nepal.

Acknowledgements: We thank National Trust for Nature Conservation (Nepal), Snow Leopard Conservancy (US), CzechGlobe-Global Change Research Center AS $\mathrm{CR}$, and Rufford Foundation, for supporting the field work. We thank Lalu Gurung, Pema Tsering, and Ghurmi Gurung, for their assistance in data-collection and camera-trapping, Charleen Gavette for helping to construct the map, and personnel of the Annapurna Conservation Area Project in Pokhara, Jomsom and LoManthang for logistic and other support.

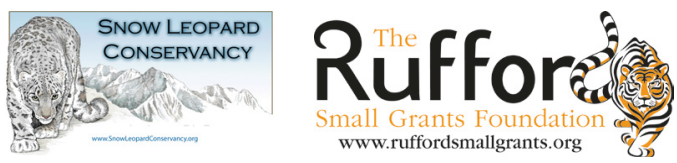




\section{INTRODUCTION AND OBJECTIVES}

The endangered Snow Leopards Panthera uncia inhabit some of the world's most rugged landscape, exemplified by the Himalaya, where they prefer steep, rugged terrain well broken by cliffs, ridges, gullies and rocky outcrops (Schaller 1977; Jackson \& Ahlborn 1989). Annapurna Conservation Area, a part of Nepal Himalaya, dominated by some of the world's tallest mountains, supports a significant proportion of Nepal's Snow Leopards estimated at 350-500 individuals (Jackson \& Ahlborn 1990). A large portion of this lies within Mustang District covering c. $47 \%$ of the Annapurna Conservation Area $\left(7,629 \mathrm{~km}^{2}\right)$ (NTNC 2008). Snow Leopards have been reported from the adjoining districts, Manang (Oli 1994) to the east and Dolpo (Jackson \& Alhborn 1990) to the west, but little is known about the population in Mustang except for anecdotal accounts of livestock losses allegedly killed by this large feline.

We explored different areas in Mustang to record the presence and current conservation status of Snow Leopards, under a joint collaboration between the Snow Leopard Conservancy (USA) and the National Trust for Nature Conservation, Nepal's largest nongovernmental environmental organization that manages the Annapurna Conservation Area. The vast and rugged land of Mustang may be one of the strategic locations where Snow Leopards from eastern and western Nepal may interbreed over time and thereby maintain their metapopulation structure. Alternately sundrenched and snow-driven, whipped and scoured by ceaseless wind, Mustang has been drained by the Kali Gandaki River which had cut the world's deepest gorge between the Annapurna $(8090 \mathrm{~m})$ and Dhaulagiri $(8167 \mathrm{~m})$ massifs.

Our specific questions in this study were: How does the abundance of Snow Leopard signs in Mustang compare to those reported elsewhere? Does the Snow Leopard have any socio-religious significance to the local people? Besides Snow Leopards and their more visible prey, the Blue Sheep Pseudois naur, Mustang also harbors the Grey Wolf Canis lupus, Lynx Lynx lynx isabellinus, and other ungulates like the nearly-threatened Tibetan Argali Sheep Ovis ammon hodgsonii and the Tibetan Gazelle Procapra picticaudata, but the latter species are mostly confined to the northern rim along the Tibet (China) border. Mustang is not only diverse in its large mammal fauna but also represents a culturally vibrant region. Sparsely inhabited by over 15,000 people, Mustang supports close to 100,000 livestock (yak, cattle, horse, mules, sheep, and goats). The region annually receives about 30,000 international trekkers within its lower reaches. Closed to foreign visitors until 1991, Mustang, acquired an aura of mystery (NTNC 2008). In the 1950s and 1960s it served as a base for the Tibetan freedom fighters or Khampa who were engaged in a futile struggle against the Chinese presence in Tibet. As recently as 2007, previously unknown Buddhist and preBuddhist religious texts and wall paintings dating from the $15^{\text {th }}$ century have been found in series of man-made caves carved onto sheer unconsolidated sandstone cliffs. These indicate Mustang served as a center for Buddhism and Bon religion for many centuries. In this study, we examined socio-religious values of Snow Leopard, and suggest their conservation implications.

\section{STUDY AREA AND METHODS}

We explored remote valleys in Mustang in 2010 (one survey) and 2011 (two surveys). Two study sites included Lower Mustang [i.e., the upper reaches of Thini, Jomsom (district headquarters), Lubra, and Muktinath], and Upper Mustang (the rugged terrain around Chhuksang, Chaile, and Somar) [Fig. 1].

Snow Leopard sign survey and habitat characterization: To detect Snow Leopard sign, we trekked across the region extensively, visiting all locations with suitable terrain and habitat where we judged Snow Leopards and their prey may occur, and established the transects employing the techniques of the Snow Leopard Information Management System (Jackson \& Hunter 1996). This is a method commonly used for monitoring Snow Leopards which is low in cost and has minimal impact on the species being studied (see Schaller 1977; Schaller 1998; Wilson \& Delahay 2001; Wolf \& Ale 2009). With the help of 1:50,000 topographic maps, we located ridgelines, narrow valleys, trails and cliff-edges, used most frequently by Snow Leopards to move about their home range (Jackson \& Hunter 1996). We randomly selected 27 of these sites for ground surveys in which we walked along sign transects of various lengths to record sign known or presumed to have been left by Snow Leopards. We concentrated on elevations between $3,000 \mathrm{~m}$ and 5,500m, which comprise a zone of dry alpine and subalpine steppe or semi steppe vegetation, the preferred vegetation cover type used by Snow Leopard. Forests are sparsely distributed largely because of the strong rain-shadow effect of the Annapurna and Dhaulagiri ranges (Stainton 1972; Dobremez 1976). The primary vegetation types are Blue Pine Pinus wallichiana and West Himalayan Fir Abies spectabilis forests at lower elevations on moist slopes, Juniper Juniperus 


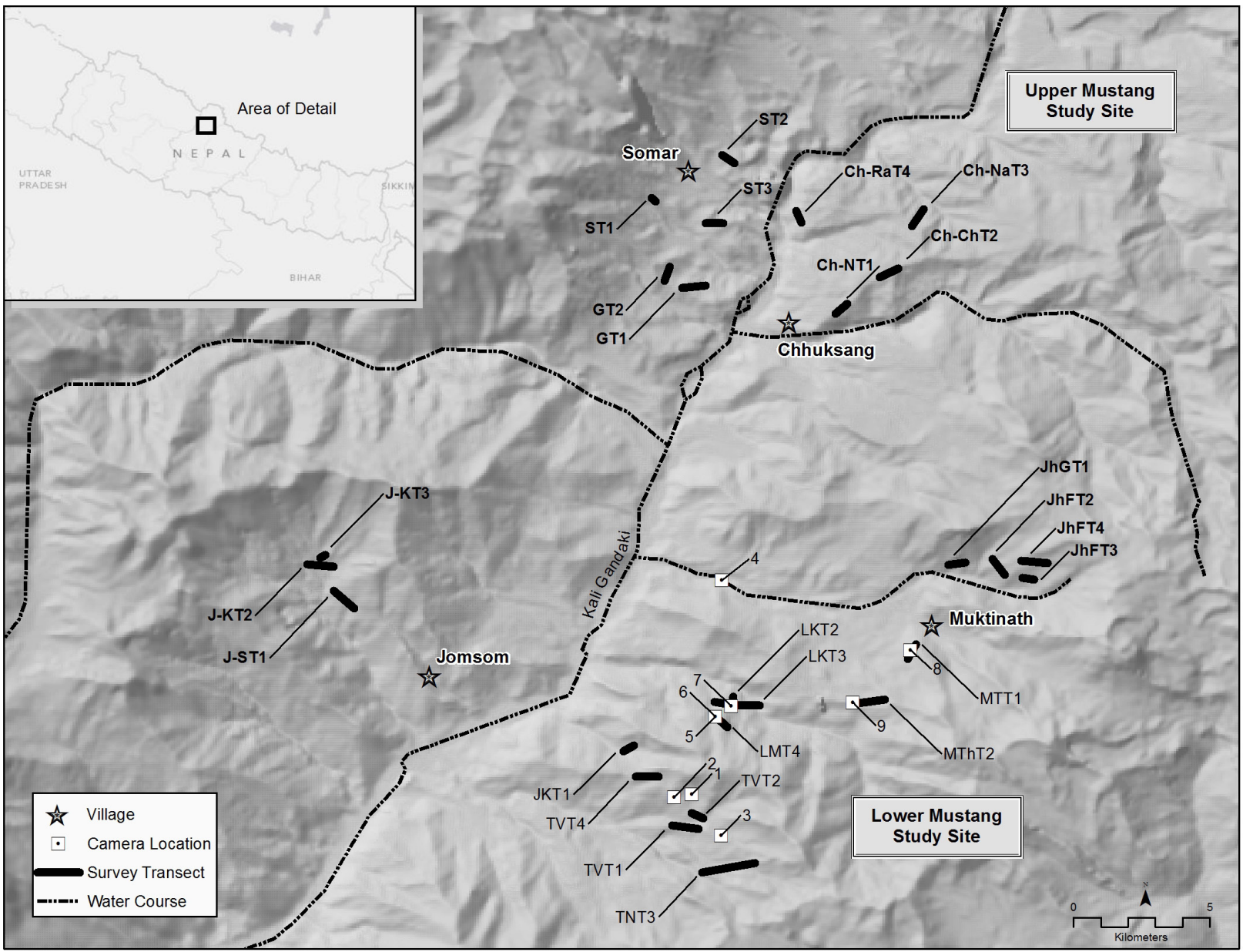

Figure 1. Mustang study area in the Annapurna Conservation Area, Nepal.

indica woodland or scrub at mid-elevations, and alpine meadows or barren snowfields and rock with scattered grasses and sedges at higher elevations. We covered $19,400.4 \mathrm{~m}$ of linear distance ( 27 transects, mean length $718.5 \mathrm{~m}$, range $=400-1000 \mathrm{~m}, \mathrm{SE}=33.8$ ).

We ran the transects during autumn (7-16 November) of 2010, and spring (1-10 May) and summer (12-27 July) of 2011, judged as the most appropriate times of year to detect sign. Each season, we ran the transect only once. In autumn 2010, we concentrated in Lower Mustang and in spring 2011 in Upper Mustang. We revisited all transects in both study sites in the summer 2011. We located and characterized sign left by Snow Leopards, including feces (scats), footprints (pugmarks), scrapes, scent (spray) marks, and boulders and rocks used by Snow Leopards to cheek-rub and deposit their scent (often located at or near active scrape sites). This is known as "transect method" in which we recorded Snow Leopard signs along pre-selected transects (see Fox et al. 1991; Mallon 1991; Jackson \& Hunter 1996). In addition to searching for leopard sign along transects (transect method), we also recorded the signs opportunistically encountered while traversing from one alpine valley to another for undertaking sign transect or to observe prey species (Blue Sheep). Snow Leopard signs encountered under this more wide-ranging "incidental detection method" provided a useful comparison to information gathered along sign transects. For each sign encountered, we recorded the date and location; the latter was determined using Garmin eTrex Venture global positioning system receivers (average 20-m accuracy; Garmin International Inc., Olathe, Kansas). We also characterized the following habitat variables within a $50 \mathrm{~m}$ radius of each sign site: elevation, slope, aspect, habitat ruggedness, and habitat type. For each 1,000m of transect length, we randomly selected four to six sites where we characterized available habitat for a total of 209 plots in Upper Mustang and 139 in Lower Mustang. To avoid spatial autocorrelation and pseudo-replication, we considered all sign found within $50 \mathrm{~m}$ distance of each other during the same year to represent a single site.

Prey (Blue Sheep) survey: While searching Snow 
Leopard sign during autumn 2010 and spring and summer of 2011, we also surveyed Blue Sheep, Snow Leopard's main local prey, opportunistically, to understand its population structure and composition. We counted all individuals of a Blue Sheep herd whenever we sighted one, and classified them into young (less than a year), yearling (1-2 years), adult female and male (over 2 years) (Schaller 1977). Some individuals obviously could not be identified because they were too far or hid behind a bush or boulder. We further classified male Blue Sheep into young male ( $2-5$ years) and old male (over 5 years).

Interviews and livestock depredation survey: We obtained socio-religious information through individual and focus-group interviews of local villagers especially herders. We randomly picked ten major villages out of the 20 settlements in two study areas to assess Snow Leopards depredation, the region's only large predator of significance in this regard. We interviewed all households in each village, and obtained information on livestock herd size and mortality over the past 12 months. We lumped livestock mortality into two categories for our study purpose: that attributed to Snow Leopards and the number of losses from all other sources, notably disease and accidents). We interviewed key informants (e.g., elderly herders, village leaders) to document their perceptions toward Snow Leopards and other wildlife. Key-informant interviews were not structured, while we used structured- or semi-structured-questionnaires for the household-surveys.

Remote-camera survey: In 2011, we deployed remotely triggered cameras to document and estimate the minimum number of Snow Leopards present in areas surveyed. Camera trapping is being increasingly deployed in monitoring of rare and shy wildlife (Karanth \& Nichols 1998; Jackson et al. 2006). We located suitable camera-trap sites along high, well-defined and narrow ridgelines or valley bottoms at or immediately adjacent to frequently scent-sprayed rocks and scrapes (Fig. 1; Jackson et al. 2006). In all we deployed nine remotely-triggered cameras (Bushnell and ScoutGuard passive infrared detector) in Lower Mustang valley, from 20 October to 25 December 2011. One camera was stolen and another malfunctioned, so that only seven cameras were fully operable during the 58day survey-period. Lower Mustang was selected for cameras-trapping instead of Upper Mustang because of its incidences of heavy livestock depredation by Snow Leopard, accessibility, and well-defined travel corridors where remote cameras could be installed to achieve a more consistent photo capture success. We selected three strategic watersheds for locating nine cameras: Four cameras were placed in the Vrapsa-Namu drainage $\left(28.76096^{\circ} \mathrm{N} \& 083.80131^{\circ} \mathrm{E}\right)$, three in Lubra $\left(28.78647^{\circ} \mathrm{N} \& 083.80904^{\circ} \mathrm{E}\right)$, and two in the Muktinath area $\left(28.80850^{\circ} \mathrm{N} \& 083.87355^{\circ} \mathrm{E}\right.$ ) (see Fig. 1 for cameralocation sites, 1 to 9). Ideally, we would have preferred to deploy our small number of cameras at a density of at least one camera per ca. $25 \mathrm{~km}^{2}$ - judged to be the minimum home range size of a female adult Snow Leopard: Jackson 1996). However, we were unable to do so due to gaps in coverage due to inaccessibility, large patches of unsuitable or poor habitat, and the large area that needed to be surveyed within a relatively short time period (three months). Each station had one cameratrap placed at a distance of 2-3 $\mathrm{m}$ from the anticipated travel path (Jackson et al. 2006). The camera-traps were checked approximately every 12-15 days, and batteries changed if necessary.

\section{RESULTS AND DISCUSSION}

Scrapes and scats represented the most frequently detected sign type (89\%), with few pugmarks or scent sprays being detected least often. Total sign abundance along all transects was 5.8 per km (3.7 scrapes/km, Table 1a). The likelihood of encountering signs was highest in spring (10.2 signs/ $\mathrm{km}$ ) and lowest in summer (2.1 signs/ $\mathrm{km})$. Our incidental method of sign search revealed 77 signs in 35 full days of searching (7-16 November 2010, 1-10 May 2011, and 12-27 July 2011). Except for pugmarks, the proportions of other sign types that we encountered along the transects were similar to signs encountered during opportunistic surveys (Table $1 b$ ).

Snow Leopard sign density in Mustang may be comparable to that reported from Mt. Everest (4.5 all signs $/ \mathrm{km}, 3.2$ scrapes $/ \mathrm{km}$ : Ale 2007). The sign density was much lower in Rolwaling in eastern Nepal (3.2 all sign $/ \mathrm{km}$, <1 scrape/km: Ale et al. 2010). Genetic sampling in Mt. Everest revealed four resident cats (Lovari et al. 2009) during the same time period, while Snow Leopards were apparently transient in Rolwaling in the Gaurishankar region (Ale et al. 2010). An unpublished report based on genotyping (Karmacharya et al. 2012) confirmed the presence of three individuals in Rolwaling. The Langu Valley, a rugged area with very sparse human habitation in western Nepal, with an estimated density of 8-10 cats $/ 100 \mathrm{~km}^{2}$ (based on 4.5 year radio-telemetry study), revealed 36 signs (all types) per km (Jackson 1996). While sign abundance in Mustang is much lower than that recorded in Dolpo, it is more frequent than Ladakh, India $\left(2.6\right.$ scrapes $/ \mathrm{km}$, with 1 cat $/ 100 \mathrm{~km}^{2}$ : Fox 
Table 1a. Snow Leopard sign abundance in Mustang, Annapurna

\begin{tabular}{|c|c|c|c|c|c|c|c|c|c|c|c|c|}
\hline & Transect & $\begin{array}{c}\text { Length } \\
(\mathrm{km})\end{array}$ & Feces & Pugmark & Scrape & Spray & Hair & Total & $\begin{array}{c}\text { Total } \\
\text { sign/ } \\
\mathrm{km}\end{array}$ & $\begin{array}{l}\text { Sign } \\
\text { sites }\end{array}$ & $\begin{array}{c}\text { Sign } \\
\text { sites/ } \\
\mathrm{km}\end{array}$ & $\begin{array}{c}\text { Scrape/ } \\
\text { km }\end{array}$ \\
\hline \multicolumn{13}{|l|}{ Season } \\
\hline Autumn & 9 & 7.2 & 19 & 10 & 33 & 4 & & 66 & 9.2 & 46 & 6.4 & 4.6 \\
\hline Spring & 15 & 11 & 15 & 6 & 90 & & 1 & 112 & 10.2 & 38 & 3.5 & 8.2 \\
\hline Summer & 27 & 19.4 & 22 & 3 & 16 & & & 41 & 2.1 & 23 & 1.2 & 0.8 \\
\hline Total & & 37.6 & 56 & 19 & 139 & 4 & 1 & 219 & 5.8 & 107 & 2.8 & 3.7 \\
\hline \multicolumn{13}{|l|}{ Study area } \\
\hline Lower Mustang & 3 & 24.4 & 45 & 15 & 56 & 4 & 1 & 121 & 5.0 & 77 & 3.2 & 2.3 \\
\hline Upper Mustang & 18 & 13.2 & 11 & 4 & 83 & & & 98 & 7.4 & 30 & 2.3 & 6.3 \\
\hline Total & & 37.6 & 56 & 19 & 139 & 4 & 1 & 219 & 5.8 & 107 & 2.8 & 3.7 \\
\hline
\end{tabular}

Table 1b. Snow Leopard signs encountered using transect method and incidental method

\begin{tabular}{|l|c|c|c|c|}
\hline & \multicolumn{2}{|c|}{ Transect method } & \multicolumn{2}{c|}{ Incidental method } \\
\hline Sign Types & Number & Freq. & Number & Freq. \\
\hline Feces & 56 & 25.6 & 14 & 18.2 \\
\hline Pugmark & 19 & 8.7 & 12 & 15.6 \\
\hline Scrape & 139 & 63.5 & 49 & 63.6 \\
\hline Spray & 4 & 1.8 & 2 & 2.6 \\
\hline Hair & 1 & 0.5 & 0 & 0.0 \\
\hline Total & 219 & 100 & 77 & 100 \\
\hline
\end{tabular}

et al. 1991) or northern Pakistan (2.4 all sign, with 1.2-2 cats $/ 100 \mathrm{~km}^{2}$ : Hussain 2003). Mustang has many broad ridges and wide U-shaped valleys, making it difficult to detect Snow Leopard signs. As noted, Snow Leopards prefer sharp-ridges at least in the Himalayas (Jackson 1996). While comparing different areas, the selection of sign-transects, and corresponding signs per unit transect length, may bias our perceptions of Snow Leopard distribution and abundance. For instance, in Ladakh, Snow Leopard signs were much more abundant along sharp ridges and river confluence (Fox et al. 1991; Mallon 1991), but in Qinghai (China) Snow Leopards marked the bases of hills flanking broad valleys where its travel routes were less well defined, thus making it difficult to locate their sign along transects (Schaller et al. 1988).

Scrapes and scent (or spray) marks are considered as the most reliable determinants of the Snow Leopard presence and abundance, while feces and pugmarks are less so. The former category of signs is expensive to produce, bio-economically speaking, while the latter may be less expensive (cf. Schaller 1977, 1998).
A non-invasive genetics study by Janecka et al. (2008) in Mongolia determined that up to $60 \%$ of all scats considered to have been deposited by Snow Leopard in fact belonged to Red Fox Vulpes vulpes.

However, sign density may offer an index of relative abundance of Snow Leopards for comparing different areas, provided that they have comparable topographies. It may be useful for monitoring abundance trends in the same location over time, as long as these are supplemented by other methods, for instance, remote cameras (e.g., McCarthy et al. 2008) or genetic sampling (e.g., Janecka et al. 2008, 2011). It has been suggested that index values can be used to estimate population size by calibrating them with estimates derived from parallel methods (Wilson \& Delahay 2001). The guesstimate of Snow Leopard numbers based on sign abundance to date follows Jackson \& Hunter (1996): 20 signs per kilometer could indicate 10 individuals per $100 \mathrm{~km}^{2}$, a crude, quick and easy-to-use method, which to date has been useful in conservation planning in countries where resources are scarce. Caughley (1977, p. 12) observed that "The majority of ecological problems can be tackled with the help of indices of density, absolute estimates of density being unnecessary luxuries." It is widely recognized that determining absolute densities of most large mammals is a complex and often controversial undertaking, with direct counts being impractical, and therefore researchers must often rely upon indirect evidence, such as tracks, scats or densities.

We found the likelihood of encountering Snow Leopard sign in Mustang was greatest in spring (10.2 signs per $\mathrm{km}$ ) and least in summer (1.2 signs per $\mathrm{km}$ ), suggesting that Snow Leopards move to higher sites that are more rugged and precipitous, and, therefore, inaccessible to humans in summer as pressures from 
livestock grazing and human presence intensify at lower elevations. It may be that Snow Leopard sign was obliterated by livestock in summer and hence the subsequent finding of lower sign abundance in summer than in autumn, but our conjecture that Snow Leopards and Blue Sheep may have moved higher up in summer were reported from elsewhere (e.g., Jackson 1996; Oli \& Rogers 1996). In any case, further study is required to validate this claim. No difference in sign density was noted between Lower and Upper Mustang (Table 1b), although the latter appears to offer much better habitat for this carnivore. The much higher scrape densities in Upper Mustang than in Lower Mustang may reflect differential terrain conditions between the two study sites: the scrapes and other signs were more visible along barren ridgelines which dominate in Upper Mustang compared to the relatively more vegetated ridges in Lower Mustang.

Our opportunistic survey on blue sheep population structure and composition revealed the overall average group size $12.6(\mathrm{SE}=1.6$, range $=1-43, \mathrm{n}=42)$ [Table 2a] . This was comparable to that reported by Oli (1996) two decades earlier in the adjoining district of Manang (mean group size in Manang, 15.6, SE=1.3, $\mathrm{n}=176$ )]. That we obviously missed many herds, in particular all-male groups, is evident from the male-to-female ratio (which was much lower than 1 ). Group size was comparatively larger in Lower Mustang than in Upper Mustang - probably a reflection of differences in terms of terrain-ruggedness and quality of habitat. Upper Mustang revealed $30 \%$ bare ground compared to Lower Mustang (21\%) from our habitat sampling plots (Upper Mustang, 209 plots; Lower Mustang 139). That Upper Mustang had a lower young-to-old male ratio than Lower Mustang may be because the region is less productive
(Table 2b), an observation in line with Schaller's (1977) opinion that productive grasslands would be expected to have a higher proportion of young males while the opposite would be the case with the ungulate population occupying degraded grasslands (i.e., rangelands with less vegetative cover or biomass). However, to our knowledge, this hypothesis is yet to be rigorously tested.

The kid-to-female ratio of Blue Sheep in Mustang is within the expected normal range $(0.6$, Table $2 b)$. The proportion of females seen with a lamb at the end of the birthing season is often used as a proxy for birth rates in ungulates (e.g., Elk Cervus elaphus L.: Eberhardt et al. 1996; White-eared Kob Kobus kob leucotis A. Smith: Fryxell 1987; Moose Alces alces L.: Laurian et al. 2000; Himalayan Tahr Hemitragus jemlahicus: Scahller 1977; Ale 2007; Lovari et al. 2009). This provides a quick, easy-to-use method to assess the overall reproductive status of ungulates, at least in open habitats where they can be more easily observed and classified according to age group. A normal range for kid-to-female ratio for ungulates is considered c. 0.6 for stable populations and c. 0.7 for a growing population.

Despite the barren landscape with its patchy vegetation, Mustang appears to support a healthy blue sheep population (e.g., reasonable kid-to-female ratio, robust physical conditions) and a relatively sound number of Snow Leopards (see below). The local people's benevolent attitudes toward wildlife, together with Annapurna Conservation Area Project's conservation actions since the early 1990s, may be credited for this. Part of the reason why Snow Leopards have been thriving and will hopefully continue to do so could possibly be attributed due to area's harsh climate, remoteness and rugged terrain which discourage visitation by outsiders. In 2007 members of a National Geographic team and

Table 2a. Blue Sheep structure and composition in Mustang, Annapurna

\begin{tabular}{|c|c|c|c|c|c|c|c|c|c|c|}
\hline & Total & Male & Female & Yearling & Kid & Unidentified & Young male & Old male & Sample & Group size (SE) \\
\hline \multicolumn{11}{|l|}{ A. Season } \\
\hline Autumn 2010 & 149 & 32 & 63 & 16 & 35 & 3 & 16 & 16 & 11 & $13.54(\mathrm{SE}=2.4)$ \\
\hline Spring 2011 & 292 & 95 & 78 & 32 & 43 & 44 & 43 & 41 & 25 & $11.68(\mathrm{SE}=2)$ \\
\hline Summer 2011 & 87 & 0 & 22 & 10 & 12 & 43 & NA & 0 & 6 & $14.5(\mathrm{SE}=6.31)$ \\
\hline Total & 528 & 127 & 163 & 58 & 90 & 90 & 0 & 0 & 42 & $12.57(\mathrm{SE}=1.57)$ \\
\hline \multicolumn{11}{|l|}{ B. Study area } \\
\hline Lower Mustang & 419 & 102 & 120 & 44 & 68 & 85 & 48 & 43 & 30 & $13.97(\mathrm{SE}=1.95)$ \\
\hline Upper Mustang & 109 & 25 & 43 & 14 & 22 & 5 & 11 & 14 & 12 & $9(\mathrm{SE}=2.13)$ \\
\hline Total & 528 & 127 & 163 & 58 & 90 & 90 & 59 & 57 & 42 & $12.57(\mathrm{se}=1.57)$ \\
\hline
\end{tabular}


Table 2b. Blue Sheep structure and composition in Mustang, Annapurna

\begin{tabular}{|c|c|c|c|c|}
\hline & \multicolumn{4}{|c|}{ Ratio of -- } \\
\hline & Kid-female & $\begin{array}{l}\text { Yearling- } \\
\text { female }\end{array}$ & $\begin{array}{l}\text { Male- } \\
\text { female }\end{array}$ & $\begin{array}{c}\text { Young-old } \\
\text { male }\end{array}$ \\
\hline \multicolumn{5}{|l|}{ A. Season } \\
\hline Autumn 2010 & 0.56 & 0.25 & 0.51 & 1 \\
\hline Spring 2011 & 0.55 & 0.41 & 1.22 & 1.05 \\
\hline Summer 2011 & 0.55 & 0.45 & 0.00 & NA \\
\hline Total & 0.55 & 0.36 & 0.78 & NA \\
\hline \multicolumn{5}{|l|}{ B. Study area } \\
\hline Lower Mustang & 0.57 & 0.37 & 0.85 & 1.12 \\
\hline Upper Mustang & 0.51 & 0.33 & 0.58 & 0.79 \\
\hline Overall & 0.55 & 0.36 & 0.78 & 1.04 \\
\hline
\end{tabular}

their local guides explored the area from Chhuksang and Ghami to the more remote Lo-Manthang and discovered a series of several centuries old caves carved into the sheer cliffs. One of the caves was christened "the Snow Leopard cave" since this elusive species' footprints were found inside.

Our sign surveys revealed only two sets of pugmarks belonging to two adult Snow Leopards in the entire region in 2010 and 2011, but exhaustive interviews with local herders suggested the existence of at least three adult Snow Leopards - one occurring singly, and two in pair.

We obtained a total of 42 pictures of Snow Leopards during nine capture events resulting in a capture success of 2.3 individuals per 100 trap nights in 2011 (Table 3). Jackson et al. (2006) reported 66 and 49 capture events (capture success 8.9 and 5.6 per 100 trap-nights) in two consecutive years of 2003 and 2004 in Hemis National
Park in India. An indication that our camera locations and/or site set-up parameters were not ideal is the large number of false images (e.g., moving vegetation) and photos of non-targeted species such as livestock, birds, and other mammals (a total of 26,661) [Table 3]. However, unlike survey by Jackson et al.(2006) in Hemis, our objective was simply to determine the minimum number of Snow Leopards in selected sites as the basis for formulating the framework for consecutive year monitoring. To assist in this, we involved local school students belonging to the Snow Leopard Scouts initiative, along with herders (who served as local guides given their knowledge of the terrain as well as wildlife).

We used pelage patterning, specifically spots on the flanks, dorsal surface of the tail, and on forehead to identify individual Snow Leopards (see Jackson et al. 2006). Neither cubs nor juveniles were captured by the remote-cameras during these surveys, although they have been digitally captured subsequently. Three individuals were documented in 2011 (Images 1-3). We could not allocate 10 images to known individuals in three different events. We conclude that our study site in Lower Mustang (an area of ca. $75 \mathrm{~km}^{2}$ ) supported a minimum of three adult Snow Leopards during the period of observation.

Key-person interviews revealed that local people had a positive attitude toward the Blue Sheep but mixed feelings toward the Snow Leopard. In high altitude settlements elsewhere in Nepal, the act of appeasing the Snow Leopard in ceremonies has been a traditional social norm. For example, Khumbu, Mount Everest and Rolwaling areas contain 'beyuls' [the fabled Shangri-la or Shambala], valleys that locals consider are hidden from evil forces and protected by mountain Gods (Ale et al. 2010). Should a person with ill intentions try to

Table 3. 2011 results of camera-traps in Annapurna

\begin{tabular}{|l|c|c|c|c|c|c|c|}
\hline & \multicolumn{4}{|c|}{ Trapping effort } & \multicolumn{3}{c|}{ Images } \\
\hline Camera station & (trap nights) & Total & Full & Partial & Non-target & False & Capture events \\
\hline Vrapsa SLC31 & 58 & NA & NA & NA & 147 & 103 & NA \\
\hline Namu SLC32 & 60 & NA & NA & NA & 297 & 7301 & NA \\
\hline Namu SLC33 & 60 & 19 & 2 & 17 & 38 & 10353 & 3 \\
\hline Lubra SLC35 & 58 & NA & NA & NA & 4 & 6923 & NA \\
\hline Lubra SLC22 & 58 & 4 & 3 & 1 & 16 & 16 & 2 \\
\hline Muktinath SLC20 & 53 & 17 & 14 & 3 & 43 & 1753 & 3 \\
\hline Muktinath SLC19 & 53 & 2 & 0 & 2 & 234 & 212 & 1 \\
\hline TOTAL & 400 & 42 & 19 & 23 & 779 & 26661 & 9 \\
\hline Per 100 trap nights & & 10.5 & 4.75 & 5.75 & 194.75 & 6665 & $\mathbf{2 . 2 5}$ \\
\hline
\end{tabular}



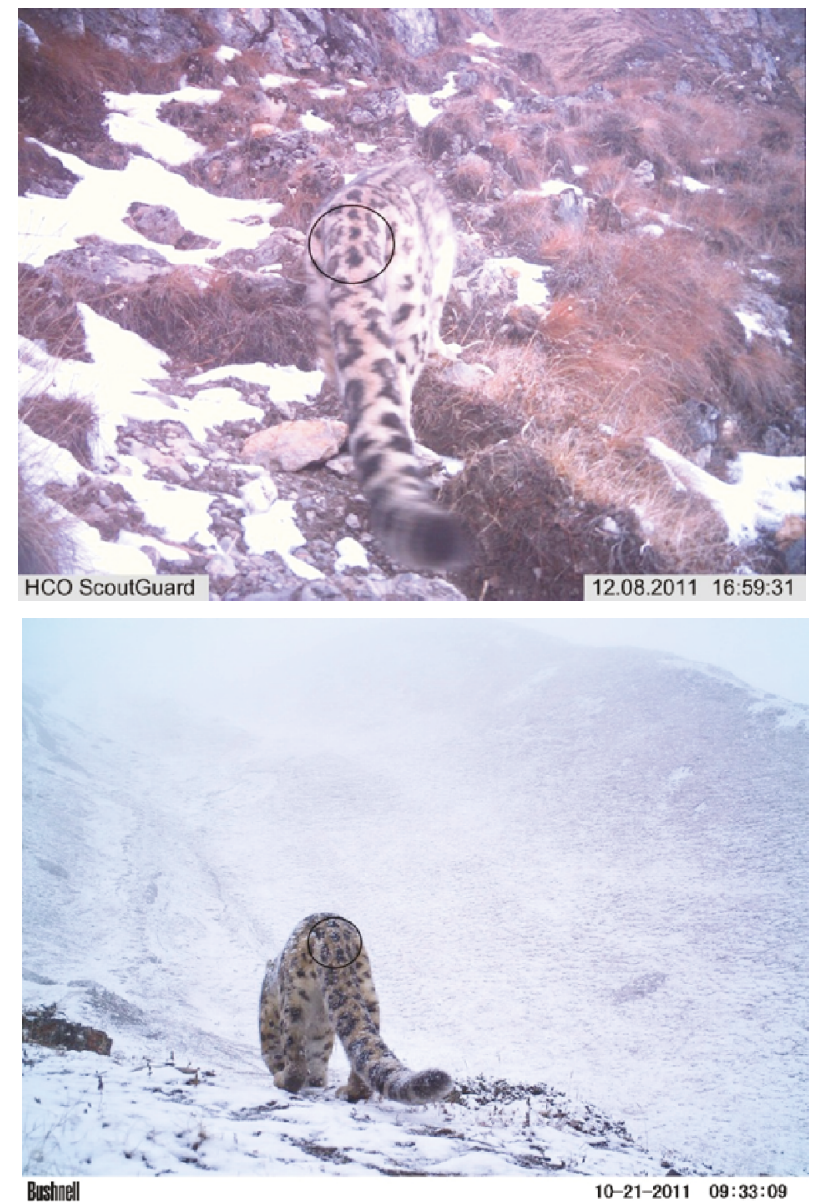

Images 1a,b. The images from Lubra station (dorsal side of tail on 12.viii.2011, Image 1a) and Namu station (dorsal side of tail on 21.x.2011, Image 1b) belonged to the same individual: Snow Leopard 1.

reach a beyul, it is believed he or she will be attacked and driven away by the Snow Leopard at the mountain pass entrance. No clear written accounts exist to affirm whether Mustang is a beyul or not, but legend has it that the $8^{\text {th }}$ century Buddhist saint 'Padma Sambhava', on his way to Tibet, stopped in Muktinath (a salvation valley for Hindu people at the elevation of $3,710 \mathrm{~m}$ - and also a religious site for Buddhists), meditated and blessed this sacred place. Legend further states that Yogi battled and defeated the local demon while travelling through Ghemi on his way to Lo-Manthang, the medieval capital of the ancient Kingdom of Lo. At the demon's demise, its intestines fell out and this is said to have led to construction of the longest prayer-wall in northern Nepal.

Local inhabitants showed mixed feelings toward Snow Leopard for good reasons: livestock-rearing, although declining, still represents a significant socio-economic activity in Mustang, and Snow Leopards often prey upon
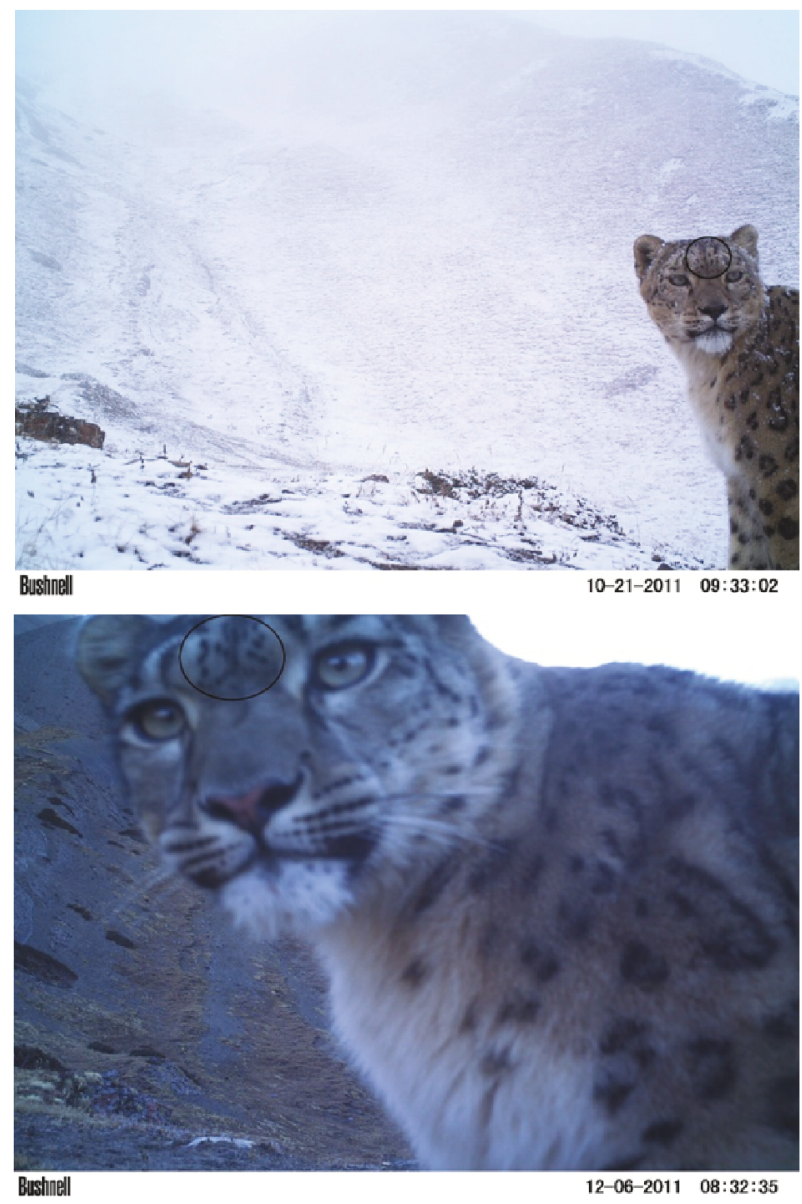

Image 2. Two different Individuals from Namu station. The facial view on 21.x.2011, Image 2a, of the same individual as in Image 1b: Snow Leopard 1. The facial view on 12.vi.2011 of a different individual, Image 2b: Snow Leopard 2.

domestic animals. As elsewhere (Mt. Everest region, for instance, see Ale et al. 2007) with increasing number of youths seeking employment in the more lucrative trekking and other businesses, the resulting labor shortage is adversely affecting current livestock herding and guarding practices. The interviews with herders in 10 selected settlements (Table 4) revealed that losses to Snow Leopard ranged from none to as high as $6.6 \%$ of livestock holdings in 2010 and 2011. Yet, villagers in settlements like Lubra suffering large livestock mortality to Snow Leopard (5.6\% of total stock per annum) are still willing to tolerate the presence of Snow Leopards, albeit uneasily. Another widely known legend states that the Bon-Po and Buddhist deities, disguised as Snow Leopard, are believed to travel from one settlement to another guarding the village's domain from demons and natural calamities. So killing a Snow Leopard may also mean harming the community's ancestral spirits. Although $3.3 \%$ of all livestock losses were attributed to 

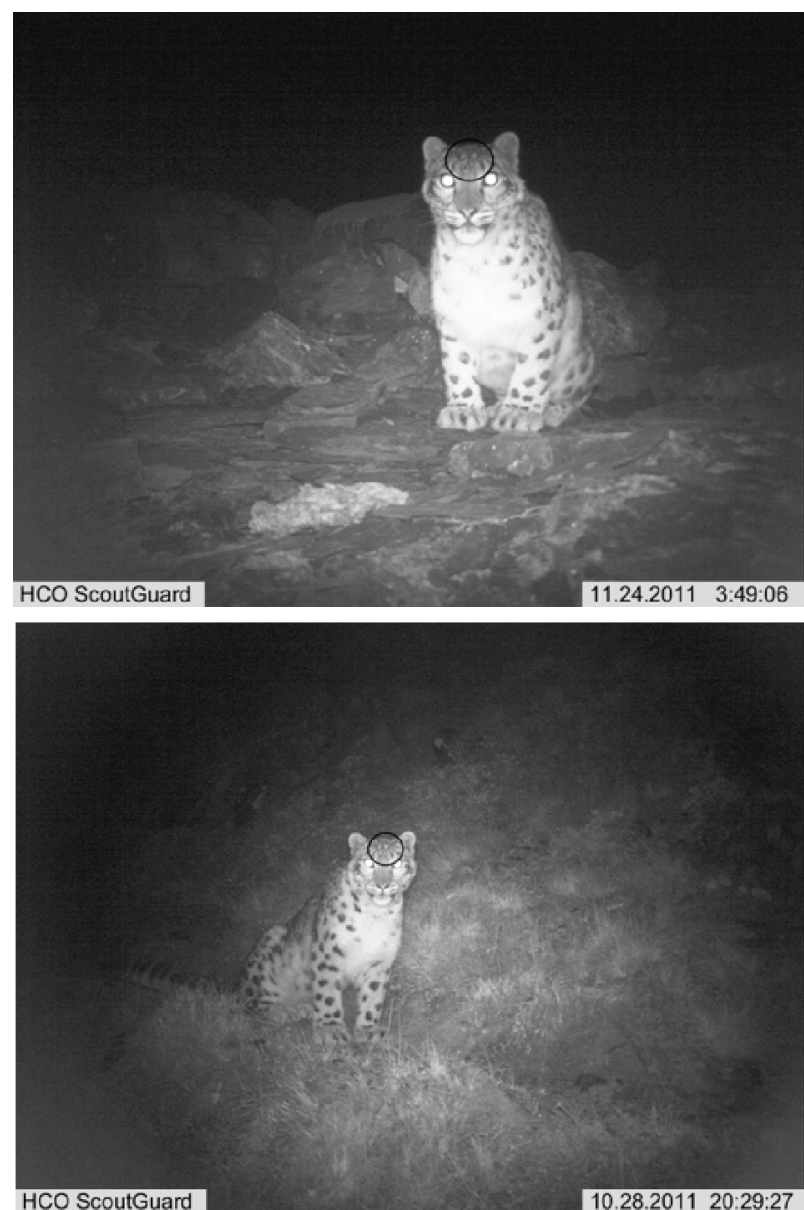

Image 3. Images captured in Muktinath in two separate instances one on 24.xi.2011 (Image 3a) and another on 28.x.2011 (Image 3b) were of the same individual: Snow Leopard 3. These stations were approx. $200 \mathrm{~m}$ apart from one another.
Snow Leopard depredation, many more animals ( $16 \%$ of total) died from other causes. The rate of livestock mortality in Mustang is similar to that has been reported from other parts of Snow Leopard range (see Jackson et al. 2010).

We conclude that Mustang offers good quality, protected habitat for the endangered Snow Leopard, and may also serve as a strategic corridor enabling leopards to disperse through this portion of the Himalayan and trans-Himalayan ranges. However, a detailed, systematic corridor assessment is needed to identify suitable Snow Leopard-corridors across the Himalaya of Nepal where conservation interventions could be best mounted. By mapping seasonal livestock movements, collecting other biological and physical variables (in addition to Snow Leopard sign data), and analyzing DNA from scats, hair and kills, it may be possible to develop an agent-based corridor model that reasonably predicts how Snow Leopards move across the landscape and respond to various management options.

\section{REFERENCES}

Ale, S.B. (2007). Ecology of the Snow Leopard and the Himalayan tahr in Sagarmatha (Mt. Everest) National Park, Nepal. PhD Thesis. Department of Biological Sciences, University of Illinois at Chicago, Chicago, 181pp.

Ale, S.B., K. Thapa, R.M. Jackson \& J.L.D. Smith (2010). The fate of Snow Leopards in and around Mt. Everest. CATnews 53: 19-21.

Ale, S.B., P. Yonzon \& K. Thapa (2007). Recovery of Snow Leopard Uncia uncia in Sagarmatha (Mount Everest) National Park, Nepal. Oryx

Table 4. Livestock mortality by Snow Leopard in Mustang in 2010 and 2011

\begin{tabular}{|c|c|c|c|c|c|c|c|c|c|c|c|c|c|}
\hline \multirow[b]{2}{*}{ Village } & \multirow[b]{2}{*}{ Household } & \multicolumn{3}{|c|}{ Livestock Type } & \multirow[b]{2}{*}{$\begin{array}{l}\text { Horse/ } \\
\text { Donkey }\end{array}$} & \multirow[b]{2}{*}{ Total } & \multicolumn{3}{|c|}{ Livestock mortality by } & \multirow[b]{2}{*}{$\%$} & \multirow{2}{*}{$\begin{array}{c}\text { Total } \\
\text { mortality }\end{array}$} & \multirow[b]{2}{*}{$\%$} & \multirow{2}{*}{$\begin{array}{c}\begin{array}{c}\text { Loss to } \\
\text { leopard }\end{array} \\
\text { per family }\end{array}$} \\
\hline & & $\begin{array}{c}\text { Sheep/ } \\
\text { goat }\end{array}$ & Cattle & Yak & & & $\begin{array}{c}\text { Snow } \\
\text { Leopard }\end{array}$ & $\%$ & $\begin{array}{l}\text { Other } \\
\text { causes }\end{array}$ & & & & \\
\hline Lubra & 14 & 388 & 43 & 15 & 17 & 520 & 29 & 6 & 28 & 5.4 & 57 & 11 & 2.1 \\
\hline Khinga & 29 & 1012 & 135 & 33 & 19 & 1199 & 0 & 0 & 612 & 51.0 & 612 & 51 & 0 \\
\hline Jharkot & 45 & 373 & 215 & 55 & 66 & 709 & 5 & 1 & 43 & 6.1 & 48 & 6.8 & 0.1 \\
\hline Purang & 20 & 0 & 62 & 12 & 15 & 89 & 0 & 0 & 3 & 3.4 & 3 & 3.4 & 0 \\
\hline Ranipauwa & 27 & 21 & 118 & 43 & 28 & 210 & 1 & 1 & 14 & 6.7 & 15 & 7.1 & 0 \\
\hline Jong & 30 & 744 & 92 & 37 & 12 & 885 & 17 & 2 & 55 & 6.2 & 72 & 8.1 & 0.6 \\
\hline Putak & 12 & 112 & 35 & 17 & 10 & 174 & 3 & 2 & 5 & 2.9 & 8 & 4.6 & 0.3 \\
\hline Tanbe & 34 & 1267 & 50 & 26 & 31 & 1374 & 40 & 3 & 106 & 7.7 & 146 & 11 & 1.2 \\
\hline Chhuksang & 27 & 588 & 174 & 39 & 31 & 832 & 55 & 7 & 75 & 9.0 & 130 & 16 & 2 \\
\hline Tetang & 37 & 2203 & 11 & 58 & 31 & 2303 & 126 & 6 & 389 & 17 & 515 & 22 & 3.4 \\
\hline Total & 275 & 6708 & 935 & 335 & 260 & 8295 & 276 & 3 & 1330 & 16.0 & 1606 & 19 & 1.3 \\
\hline
\end{tabular}


41(01): 89-92; http://dx.doi.org/10.1017/\$0030605307001585

Caughley, G. (1977). Analysis of Vertebrate Populations. Brisbane: John Wiley \& Son, 234pp.

Dobremez, J.F. (1976). Le Nepal: Ecologie et Biogeographie. Editions du Centre National de la Recherche Scientifique, Paris, 356pp.

Eberhardt, L.E., L.L. Eberhardt, B.L. Tiller \& L.L. Cadwell (1996). Growth of an isolated elk population. Journal of Wildlife Management 60(2): 369-373.

Fox, J.L., S.P. Sinha, R.S. Chundawat \& P.K. Das (1991). Status of the Snow Leopard in northern India. Biological Conservation 55(3): 283-298; http://dx.doi.org/10.1016/0006-3207(91)90033-6

Fryxell, J.M. (1987). Food limitation and demography of a migratory antelope, the white-eared kob. Oecologia 72(1): 83-91; http:// dx.doi.org/10.1007/BF00385049

Hussain, S. (2003). The status of the Snow Leopard in Pakistan and its conflict with local farmers. Oryx 37(01): 26-33; http://dx.doi. org/10.1017/S0030605303000085

Jackson, R. (1996). Home range, movements and habitat use of Snow Leopard in Nepal, PhD Thesis. University of London, UK, 233pp.

Jackson, R. \& D.O. Hunter (1996). Snow Leopard Survey and Conservation Handbook. International Snow Leopard Trust and U. S. National Biological Service, 154pp.

Jackson, R. \& G. Ahlborn (1989). Snow Leopards (Panthera uncia) in Nepal - home range and movements. National Geographic Research and Exploration 5: 161-75.

Jackson, R. \& G. Ahlborn (1990). The role of protected areas in Nepal in maintaining viable population of Snow Leopards. International Pedigree Book of Snow Leopard 6: 51-69.

Jackson, R., J.D. Roe, R. Wangchuk \& D.O. Hunter (2006). Estimating Snow Leopard population abundance using photography and capture-recapture techniques. Wildlife Society Bulletin 34(3): 772781; http://dx.doi.org/10.2193/0091-7648(2006)34[772:ESLPAU]2 .0.CO;2

Jackson, R.M., C. Mishra, T.M. McCarthy \& S.B. Ale (2010). Snow Leopards: conflict and conservation, pp. 417-430. In: David, W.M. \& J.L. Andrew (eds). The Biology and Conservation of Wild Felids. Oxford University Press.

Janečka, J.E., B. Munkhtsog, R.M. Jackson, G. Naranbaatar, D. Mallon \& W.J. Murphy (2011). Comparison of noninvasive genetic and camera-trapping techniques for surveying Snow Leopards. Journal of Mammalogy 92(4): 771-783; http://dx.doi.org/10.1644/10MAMM-A-036.1

Janečka, J.E., R. Jackson, Z. Yuguang, L. Diqiang, B. Munkhtsog, V. Buckley-Beason \& W.J. Murphy (2008). Population monitoring of Snow Leopards using noninvasive collection of scat samples: a pilot study. Animal Conservation 11(5): 401-411; http://dx.doi. org/10.1111/j.1469-1795.2008.00195.x

Karanth, K.U. \& J.D. Nichols (1998). Estimation of tiger densities in India using photographic captures and recaptures. Ecology 79(8): 28522862; http://dx.doi.org/10.1890/0012-9658(1998)079[2852:EOTDII ]2.0.CO;2
Karmacharya, D., J. Janecka, S.B. Ale, J. Shakya, P. Joshi, S. Manandhar, S. Shrestha, C. Kansakar \& A. Awasthi (2012). Genetic based population survey of Snow Leopard (Pantheria uncia) in Annapurna Conservation and Rolwaling areas of Nepal. Final Report Submitted to Snow Leopard Conservation Grants, Snow Leopard Network. http://www.snowleopardnetwork.org/GrantFinalReports/ KarmacharyaFinal11.pdf

Laurian, C., J.P. Ouellet, R. Courtois, L. Breton \& S. St Onge (2000). Effects of intensive harvesting on moose reproduction. Journal of Applied Ecology 37(3): 515-531; http://dx.doi.org/10.1046/j.13652664.2000.00520.x

Lovari, S., R. Boesi, I. Minder, M. Mucci, E. Randi, A. Dematteis \& S.B. Ale (2009). Restoring a keystone predator may endanger a prey species in a human-altered ecosystem: the return of the Snow Leopard to Sagarmatha National Park. Animal Conservation 12(6): 559-570; http://dx.doi.org/10.1111/j.1469-1795.2009.00285.x

Mallon, D.P. (1991). Status and conservation of large mammals in Ladakh. Biological Conservation 56(1): 101-119; http://dx.doi. org/10.1016/0006-3207(91)90092-N

McCarthy, K.M., M. Ma, T.K. Fuller, T.M. McCarthy \& K. Jumabay (2008). Assessing estimators of Snow Leopard abundance. Journal of Wildlife Management 72(8): 1826-1833; http://dx.doi. org/10.2193/2008-040

NTNC (2008). Sustainble Develeopment Plan of Mustang. NTNC/ GoN/UNEP Kathmandu, Nepal. Unpub. Report. http://www.rrcap. ait.asia/nsds/uploadedfiles/file/sa/np/mnmt/document/sd_ masterplan_Mustang.pdf

Oli, M.K. (1994). Snow Leopards and Blue Sheep in Nepal: Densities and predator-prey ratio. Journal of Mammalogy 75(4): 998-1004; http://dx.doi.org/10.2307/1382482

Oli, M.K. \& M.E. Rogers (1996). Group size and population composition of Blue Sheep in Nepal. Journal of Wildlife Management 60: 797801.

Schaller, G.B. (1977). Mountain Monarchs: Wild Sheep and Goats of the Himalaya. Chicago: University of Chicago Press, 425pp.

Schaller, G.B. (1998). Wildlife of The Tibetan Steppe. The University Chicago Press, Chicago, 373pp.

Schaller, G.B., R. Junrang \& Q. Mingjiang (1988). Status of the Snow Leopard in Qinghai and Gansu provinces, China. Biological Conservation 45(3): 179-194; http://dx.doi.org/10.1016/00063207(88)90138-3

Stainton, J.D.A. (1972). Forests of Nepal. John Murray, London, 174pp. Wilson, G.J. \& R.J. Delahay (2001). A review of methods used to estimate the abundance of terrestrial carnivores using field signs and observation. Wildlife Research 28(2): 151-164; http://dx.doi. org/10.1071/WR00033

Wolf, M. \& S.B. Ale (2009). Signs at the top: habitat features influencing Snow Leopard Uncia uncia activity in Sagarmatha National Park, Nepal. Journal of Mammalogy 90(3): 604-611; http://dx.doi. org/10.1644/08-MAMM-A-002R1.1 